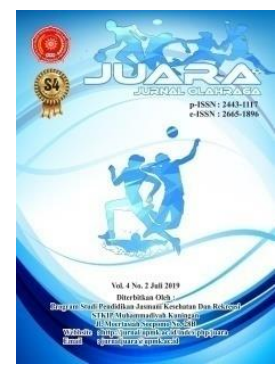

\title{
Variation Analysis of Body Position Angle of the Race Athlete on Sprint
}

ZeinFiqri Habibie ${ }^{1}$, Danang Ari Santoso ${ }^{2}$, Arya T Candra ${ }^{3}$

${ }^{1,2,3}$ Faculty of Sports and Health, Universitas PGRI Banyuwangi, Street Ikan Tongkol No.22, Kec. Banyuwangi, Banyuwangi Regency, East Java 68416, Indonesia

email: abizein94@yahoo.com¹, danangarisantoso@gmail.com², aryacandra0189@gmail.com³

\begin{tabular}{l}
\hline Info Artikel \\
\hline Article History: \\
Received 03 June 2020 \\
Approved 24 October 2020 \\
Published 18November 2020 \\
\hline Keywords: \\
Athlete's Body Angle, \\
Wind Resistance, \\
Aerodynamics \\
\hline
\end{tabular}

\begin{abstract}
This study aims to analyze the athlete's body position when the sprint race ahead of the opponent in minimizing air exposure (drag effect). The research method used was an experimental, descriptive quantitative approach. The analyzed angle variables are $45^{\circ}, 50^{\circ}, 55^{\circ}$ with wind speed flow patterns at 3 points, namely front, top, and back. The results showed the force used to hold the turning angle at a $45^{\circ}$ variation of $26739.593 \mathrm{~N}$, a $50^{\circ}$ angle variation of $28971.434 \mathrm{~N}$, and at an interpretation of $55^{\circ}$ of $30975.985 \mathrm{~N}$. Based on the force used, it can be concluded that $45^{\circ}$ angle variations are most effective in sprinting, because the position of the body at this angle narrows the air resistance on the bicycle racer so that it becomes light.
\end{abstract}

(C) 2021 ZeinFiqri Habibie, Danang Ari Santoso, Arya T Candra

Under the license CC BY-SA 4.0

\footnotetext{
$凶$ Address Corresponden: Street Ikan Tongkol No.22, Kec. Banyuwangi, Banyuwangi Regency, East Java

E-mail: danangarisantoso@gmail.com
}

\section{INTRODUCTION}

Sport is a form of physical exercise that can improve physical fitness if it is done with the right and appropriate frequency and intensity (Penggalih et al., 2015) and cannot be separated from the presence of movements which will then involve various structures/tissues in the human body, for example, joints, muscle, meniscus/discus, and capsuloligamenter (Setiawan, 2011).

Bicycle racing is a sport that has historically been victorious in West Sumatra in the past. Many cycling athletes come from West Sumatra, including Dasrizal from Payakumbuh and others. However, recently, the development of bicycle racing achievements in West Sumatra has decreased in all respects, both enthusiasts and achievements. However, in recent years the West Sumatra Government, through the West Sumatera Tourism Office, has routinely held a bicycle racing championship known as the Tour de Singkarak.

Bicycle racing is a race to reach the final finish goal in the fastest possible time and requires high endurance because this sport is a sport that uses a long time (Agus \& Rifhaatul, 2018). Bicycle racing consists of various types, including the marathon, tour de France, mountain bikes, trail, and speed bikes.

Aerodynamics is the study of how a solid object moves through the air. The field of science that studies the motion of an item due 
to air resistance is aerodynamics. This field of science is a branch of dynamics that deals with the study of air movement. Aerodynamics studies drag (drag effect) on an athlete's activity (Norstrud, 2008). When this definition is linked to the sport of cycling, it refers to how a cyclist copes with the air resistance generated by forwarding motion and wind. Two factors determine the speed that can be achieved on a bicycle. Namely, the first is how much force the rider exerts, and the second is wind resistance, often referred to as "drag force" (Utomo \& Iqbal, 2012).

The aerodynamic aspect of bicycle racing is very influential on speed. The efficiency of body position in maintaining movement speed after maximum speed is reached (Rahim, 2011). In principle, wind pressure has a movement opposite the motion force of an object to be heavier if it hits an item with a larger mass. As the opinion (Rahayu et al., 2014) states that the air resistance force has a direction opposite to the direction of motion of the object, the resistance force will be felt if the item is moving at high speed with a large surface area of the thing.

When aerodynamics is discussed in cycling, it will also give rise to several variations in the athlete's body angle. According to (Sovndal, 2009), the muscles in the leg will provide additional power curves in the pedaling motion of the bicycle and help stabilize the ankle on the pedal. The lack of knowledge in knowing the correct position angle against a cyclist often results in difficulties for an athlete himself. The problem that a bicycle racing athlete often experiences is core stability; core stability is the work stability of the spine, pelvis, glutes, and abdominal muscles.

According to (Clarsen et al., 2010) in his study, $45 \%$ of professional cyclists experienced lower back pain disorders, and $20 \%$ reduced cycling activities to restore their lower back pain conditions. Back pain can also be caused by an improperly sized bicycle, a wrongly sized bike can cause rapid fatigue, difficult bicycle control, and ultimately affect the resulting speed (Marsden \& Schwellnus, 2010).

Understanding the body's angle with the bicycle during the sprint is very important for the racer to help reduce wind resistance (drag effect) so that the force used is small and benefits the racer. Therefore, analysis of the angle during the sprint is critical to determine the effective angle in minimizing wind resistance (drag effect). With this research, it is hoped that it will become an evaluation material for coaches in providing models and forms of training to their athletes.

\section{METHODS}

This type of research is a descriptive analysis using a quantitative approach. According to (Maksum, 2012), a descriptive study is a research conducted to describe these symptoms, phenomena, or events. Meanwhile, quantitative research is a method using instruments and processes, and the results of the analysis have a quantitative or statistical nature (Mulyadi, 2013). This study describes the variation in the athletes' position in cycling during sprints to provide education and comfort to athletes in cycling competitions.

The tools and media used are 1) miniature bicycle simulation framework, 2) anemometer, and 3) wind tunnel (Howell et al., 2010). With research procedures: making a tiny bicycle simulation frame, preparing tools and materials, placing the position at an angle of $45^{\circ}, 50^{\circ}$, and $55^{\circ}$. 
Figure 1. Angle Position $45^{\circ}, 50^{\circ}$ dan $55^{\circ}$
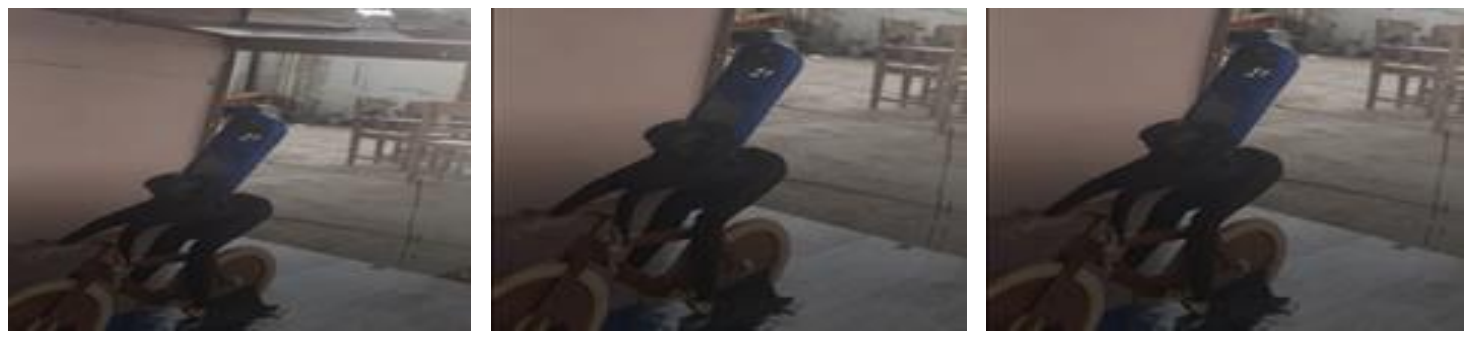

Turning on fans at different speeds, patterns and variations in body position angles, video documentation visualizing wind flow and collecting data.

patterns, repeating experiments of wind flow

Figure 2. Data Retrieval Visualization

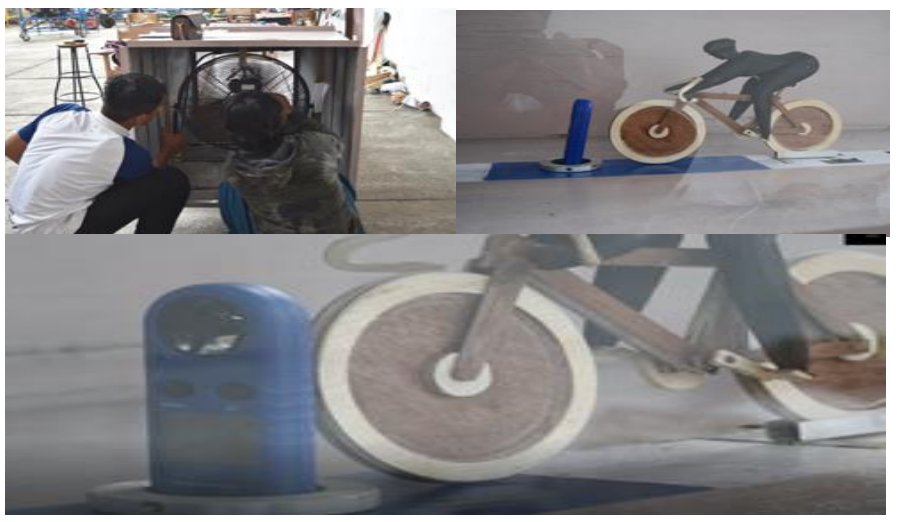

Figure 3. Tool Design

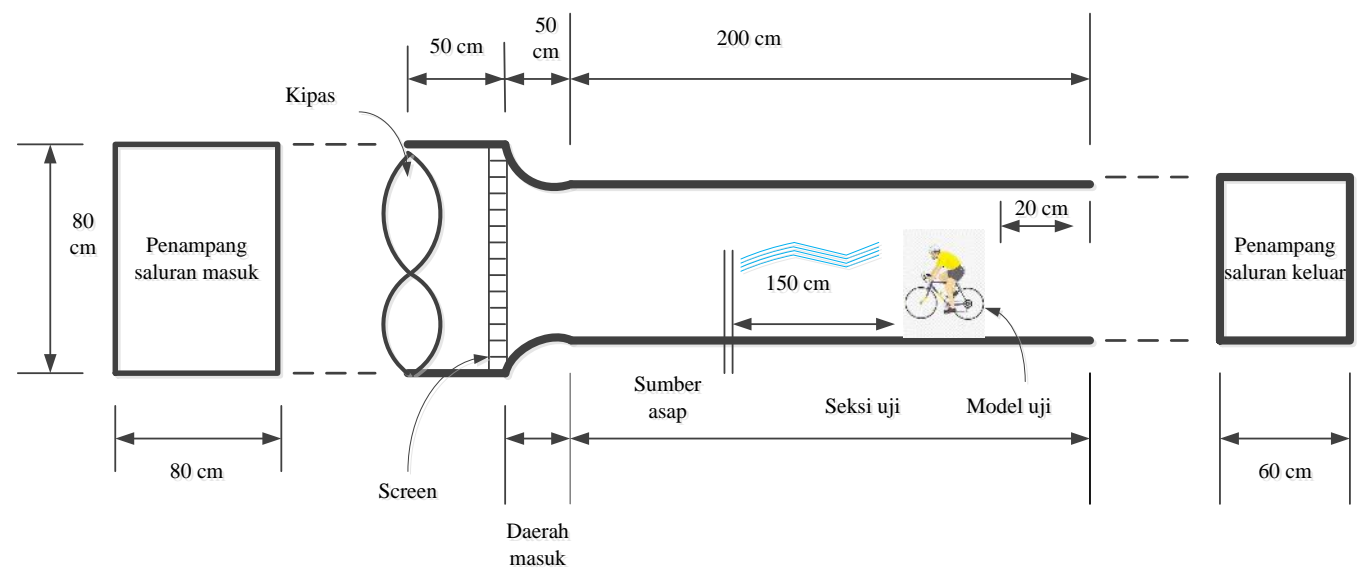

The calculations in this study were carried out using aerodynamic principles as in the calculation of the formula as follows:

$$
\begin{aligned}
& F=F_{D} \frac{1}{2} C_{d} A V^{2} \\
& F=m \cdot g \cdot \sin \alpha \\
& F=F_{D}
\end{aligned}
$$

$m \cdot g=\frac{1}{2} C_{d} A V^{2}$

$C_{d}=2 \frac{m \cdot g}{A V^{2}}$

Information:

$\mathrm{m}=$ mass of bike + racer

$\mathrm{g}=$ coefficient of gravity

$\mathrm{A}=$ cross-sectional area

$\mathrm{V}=$ wind speed (measured)

$\mathrm{Cd}=$ drag coefficient 


\section{FINDINGS AND DISCUSSION}

\section{Findings}

Based on the variation in the measured athlete's body angle, the calculation results can be explained as follows:

\section{Angle $4^{0}$}

The research results on the angular position of the bicycle racing athletes at $45^{\circ}$ angle variations with variations of three wind speeds and three measurement criteria, namely the measurement of the part of the top, rear, and front of the object of the bicycle.

Figure 4. Angle of the measured body

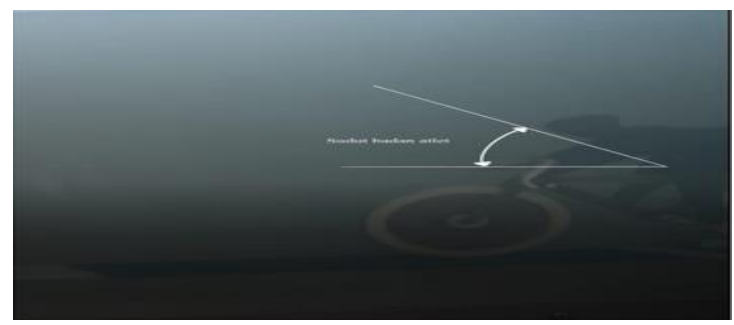

Graph 1. Wind Resistance Results $45^{\circ}$

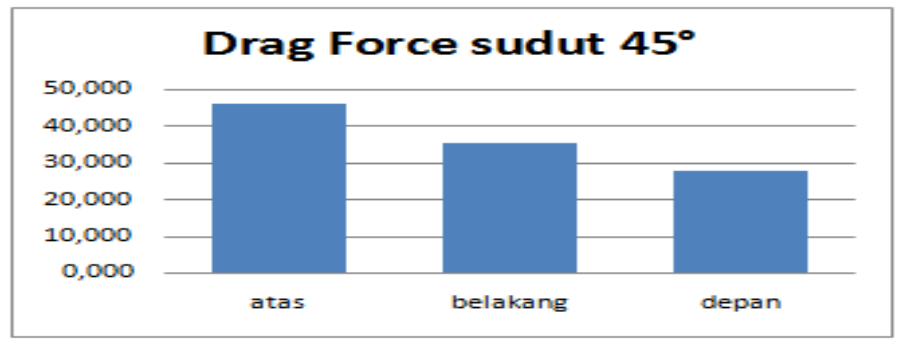

Graph 2. Result of Calculation of Angular Wind Resistance $45^{\circ}$

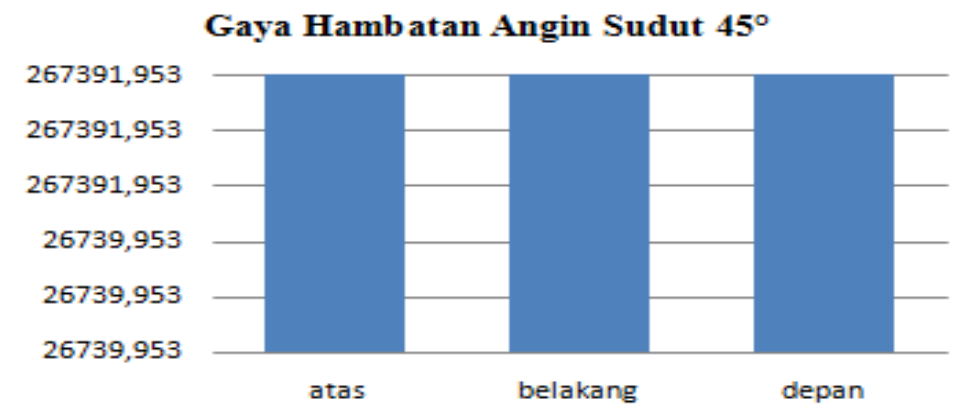

Calculation of table 1 at an angle of $45^{\circ}$ there are three calculations, namely calculating the wind flow pattern $(\mathrm{F})$, wind resistance $(\mathrm{Cd})$, and wind resistance force $(\mathrm{Fd})$. The analysis is then continued by calculating the drag coefficient (wind resistance) to determine the wind resistance that collides with the object by taking into account the different wind speeds in each measurement. From the measurement results of wind speed, it will be known as wind resistance $\left(\mathrm{C}_{-} \mathrm{d}\right)$. The calculation of $\mathrm{C}_{-} \mathrm{d}$ on each criterion has several differences so that the $\mathrm{C}_{-} \mathrm{d}$ value is different for each bar. The difference in value that occurs can be seen in table 1 ; the smallest is when the measurement is above the object, then the matter becomes more significant when measuring the back of the item, and the biggest is the measurement in front of the thing. This is due to the limitations of the fan used so that the wind flow becomes turbulent.

The results shown in the calculation 
show that the same value is due to the wind resistance, which is influenced by weight, gravity, and the athlete's angle, which has the same result, which affects the drag force that occurs. The more excellent the wind resistance, the greater the wind resistance a bicycle athlete must resist.

\section{Angle 50}

The second is the result of research on cyclist athletes' angular position at a variation of the angle of $50^{\circ}$ with a variation of three wind speeds and three measurement criteria, namely the measurement of the upper, rear, and front position of the bicycle object.

Graph 3. Result of Angle Wind Resistance of $50^{\circ}$ and Result of Calculation of Wind Resistance Angle 50

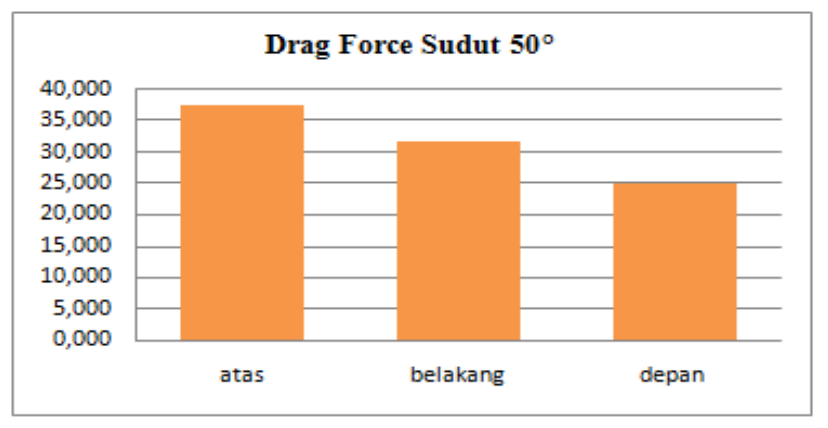

In the calculation of the $50^{\circ}$ angle, there are three calculations, namely calculating the wind flow pattern $(\mathrm{F})$, wind resistance $(\mathrm{Cd})$, and wind resistance force $(\mathrm{Fd})$. The result of wind resistance at an angle of $50^{\circ}$ is greater than that of a $45^{\circ}$ shrinkage because the total wind speed at an angle of $50^{\circ}$ will be more incredible. After all, the athlete model's tilt angle has a large surface area. The calculation is then continued by calculating the drag coefficient (wind resistance) to determine the wind resistance that collides with the object by taking into account the different wind speeds in each measurement. From the measurement results of wind speed, it will be known as wind resistance (C_d).

The calculation of $\mathrm{C} \_\mathrm{d}$ for each criterion has several differences so that the C_d value becomes a distinct difference for each measure. The difference in the deal that occurs can be seen in Table 2; the smallest is when the measurement is above the object, then the value continues to be more significant when measuring the back of the item, and the biggest is the measurement in front of the thing. This is due to the limitations of the fan used so that the wind flow becomes turbulent.
Gaya Hambatan Angin Sudut $50^{\circ}$

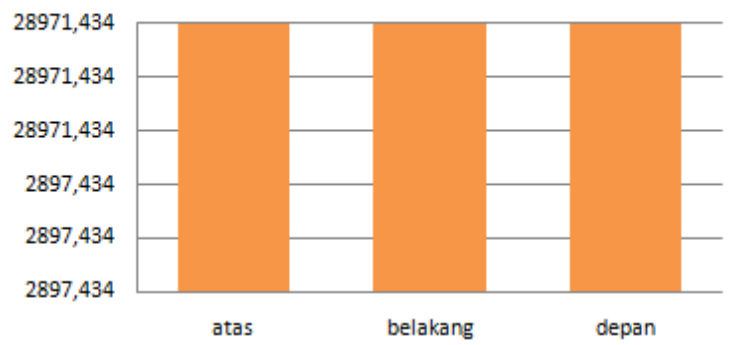

The results shown in the calculation show that the same value is due to the wind resistance, which is influenced by weight, gravity, and the athlete's angle, which has the same result, which affects the drag force that occurs. The more excellent the wind resistance, the greater the wind resistance that a bicycle racing athlete must resist. A more precise result can be seen in the graph in Figure 3. At this $50^{\circ}$ angle, the wind resistance becomes more significant so that the product is less aerodynamic, was the more influential the angle of inclination that collides on the athlete, the more excellent the wind resistance.

\section{Sudut $\mathbf{5 5}^{\mathbf{0}}$}

The research results on the angular position of the bicycle racing athletes at the angle variation of $55^{\circ}$ with the interpretation of three wind speeds and three measurement criteria, namely the measurement of the position of the top, rear, and front of the object of the bicycle. 
Graph 5. Result of Angle Wind Resistance of 55

and Result of Calculation of Wind Resistance Angle 55

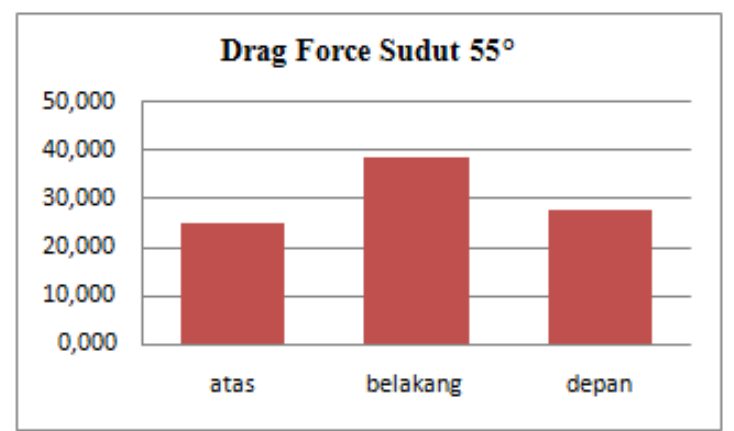

Calculation of table 4.3 in the analysis at an angle of $55^{\circ}$ there are three calculations, namely calculating the wind flow pattern $(\mathrm{F})$, wind resistance $(\mathrm{Cd})$, and wind resistance force $(\mathrm{Fd})$. The analysis is then continued by calculating the drag coefficient (wind resistance) to determine the wind resistance that collides with the object by taking into account the different wind speeds in each measurement. From the measurement results of wind speed, it will be known as wind resistance (C_d).

The calculation of C_d for each criterion has several differences so that the $\mathrm{C}_{-} \mathrm{d}$ value becomes a distinct difference for each measure. The difference in value that occurs

\section{Gaya Hambatan Angin Sudut 55}

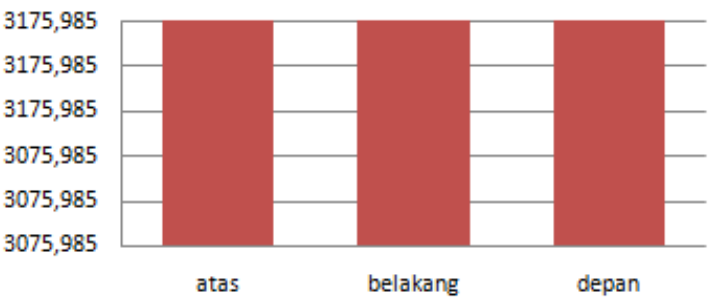

can be seen in table 4.3; the smallest is when the measurement is above the object, then the matter continues to be more significant when measuring the back of the item, and the biggest is the measurement in front of the thing. This is due to the limitations of the fan used so that the wind flow becomes turbulent.

The results shown in the calculation show that the same value is due to the wind resistance, which is influenced by weight, gravity, and the athlete's angle, which has the same result, which affects the drag force that occurs. The more excellent the wind resistance, the greater the wind resistance that a bicycle racing athlete must resist.

Table 4. Comparison of Wind Resistance

\begin{tabular}{cc}
\hline Angle Variation & Resistance Force $\left(\mathrm{F}_{\mathrm{d}}\right)$ \\
\hline $45^{\circ}$ & 26739.953 \\
$50^{\circ}$ & 28971.434 \\
$55^{\circ}$ & 30975.985 \\
\hline
\end{tabular}

\section{Discussion}

The cyclist's body position during the sprint using the $45^{\circ}$ body position model will narrow the air resistance hitting the bicycle racing athlete so that the athlete's air resistance will be lighter. The greater the tilt angle of a bicycle racing athlete, the greater the body part's surface area that has to withstand air resistance, so this causes less aerodynamic properties. The larger tilt angle has changed the wind flow to turn as a result of the collision with the surface area of the front of the model so that this shows a considerable drag (Wind resistance) as well (Rubiono, 2017). The magnitude of this drag indicates that there is a loss in wind flow pressure.

The smaller the athlete's angular position, the more risk an athlete falls off the bicycle. Because when an athlete is leaning forward, it will be challenging to maintain balance when controlling the bike so that the risk of falling will be higher. Vice versa, if the more significant the angle, it will be easier for an athlete to maintain and control the bicycle. 
However, with a smaller body position angle, the wind resistance will be lighter so that during the sprint, the athlete will find it easier to reach the finish. According to (Abdurohman et al., 2016) also explained that changes in fluid flow could affect the resistance force, modification of an electric car body with a maximum pressure of $83.2143 \mathrm{~Pa}$ produces a smaller resistance force (Prihadnyana et al., 2017).

Apart from the angle, the wind speed also affects the drag force; at an angle of $55^{\circ}$, the wind speed is greater than the $45^{\circ}$ and $50^{\circ}$ tips. The most significant drag occurs at an angle of $55^{\circ}$, this finding is by the results of research (Wulandari, 2010), where the more influential the speed, the greater the drag coefficient on the Argo variation Lawu train locomotive.

The practical contribution of the drag coefficient. Aerodynamic behavior simulation in steady and unsteady conditions in a car resembles the Toyota Avanza with Cfd (Nofianto, 2014). This study resulted in a simulation obtained from the CFD package on each model A and model B car. The drag coefficient (CD) was 0.531 and 0.495 , which proved that the drag coefficient $(\mathrm{Cd})$ decreased by $6.78 \%$. The lift coefficient (CL) in each model of 0.0396 and 0.0202 demonstrates a decrease in the lift coefficient (CL) of $48.99 \%$.

This means that the variation in the angle applied in this study is directly proportional to the analysis results above, where there is a decrease in the drag force coefficient, which also occurs at the $45^{\circ}$ angle variation.

\section{CONCLUSION}

An angle of $45^{\circ}$ is the most influential position in narrowing the wind resistance so that the air resistance faced by the athlete will be lighter. However, it is hoped that further research will be carried out analyzing effective angles when a sprint overtakes other racers.

\section{ACKNOWLEDGMENTS}

The authors would like to thank the supervisor, the Health and Recreation Physical Education Study Program, and Universitas PGRI Banyuwangi, who helped this research.

\section{REFERENCES}

Abdurohman, A., Trimulyono, A., \& Amirudin, W. (2016). Analisa Hambatan Angin Dan Stabilitas Kapal Super Container 18.000 Teus (Malacca-Max). 4(1), 91-100.

Agus, A., \& Rifhaatul, H. (2018). Pengaruh Pemberian Suplemen Elecrolyte Fuel System (Efs) Terhadap Peningkatan Daya Tahan Kecepatan Atlet Balap Sepeda Kota Padang. Sporta Saintika, 423-431.

Clarsen, B., Krosshaug, T., \& Bahr, R. (2010). Overuse Injuries In Professional Road Cyclists. The American Journal of Sports Medicine, 38(12). Https://Doi.Org/Https://Doi.Org/10.1177/ 0363546510376816

Howell, R., Qin, N., Edwards, J., \& Durrani, N. (2010). Wind Tunnel And Numerical Study Of A Small Vertical Axis Wind Turbine.

35. Https://Doi.Org/10.1017/S147090310500 3639

Maksum, A. (2012). Metodologi Penelitian Dalam Olahraga. Surabaya: Unesa University Press.

Marsden, M., \& Schwellnus, M. (2010). Lower Back Pain In Cyclists: A Review Of Epidemiology, Pathomechanics And Risk Factors. International Sportmed Journal, 11(1), 216-225.

Mulyadi, M. (2013). Penelitian Kuantitatif Dan Kualitatif Serta Pemikiran Dasar Menggabungkannya. Jurnal Studi Komunikasi Dan Media, 15(1), 128. Https://Doi.Org/10.31445/Jskm.2011.150 106

Nofianto, M. R. (2014). Simulasi Perilaku Aerodinamika Dalam Kondisi Steady Dan Unsteady Pada Mobil Menyerupai Toyota Avanza Dengan Cfd. 1-40.

Norstrud, H. (2008). Sport Aerodynamics,. Norwegian University Of Science And 
Technology Trondheim, Norway, Springer Wien, New York.

Penggalih, M. H. S. T., Hardiyanti, M., \& Sani, F. I. (2015). Perbedaan Perubahan Tekanan Darah Dan Denyut Jantung Pada Berbagai Intensitas Latihan Atlet Balap Sepeda. Jurnal Keolahragaan, 3(September), 218-227.

Prihadnyana, Y., Widayana, G., \& Dantes, K. R. (2017). Analisis Aerodinamika Pada Permukaan Bodi Kendaraan Mobil Listrik Gaski (Ganesha Sakti) Dengan Perangkat Lunak Ansys 14.5. Jurnal Pendidikan Teknik Mesin Undiksha, 5(2). Https://Doi.Org/10.23887/Jjtm.V5i2.112 46

Rahayu, S., Sahbana, M. A., \& Farid, A. (2014). Study Exsperimental Pengaruh Sudut Kemiringan Model Kendaraan Sedan Terhadap Tekanan Hisap Dalam Wind Tunel. 6(1), 54-61.

Rahim, A. A. (2011). Aplikasi Pendekatan Latihan Interval Teratur Dalam Meningkatkan Kemampuan Kecepatan Nomor Lari 100 Dan 200 Meter Pada
Siswa Smp. Jurnal Ilara, 11(1), 47-54.

Rubiono, G. (2017). Studi Visualisasi Aerodinamika Model Sudut Kemiringan Badan Pelari. Dinamika Teknik Mesin, 7(1), 22-27. Https://Doi.Org/10.29303/D.V7i1.3

Setiawan, A. (2011). Faktor Timbulnya Cedera Olahraga. Jurnal Media Ilmu Keolahragaan Indonesia, 1(1), 94-98. Https://Doi.Org/10.15294/Miki.V1i1.114 2

Sovndal, S. (2009). Cycling Anatomy. Human Kinetics.

Utomo, M. T. S., \& Iqbal, M. (2012). Analisa Aerodinamika Pada Sepeda Dengan Formasi Beriringan Dengan Variasi Kecepatan Dan Jarak Antar Sepeda Menggunakan Cfd Fluent 6.3. Rotasi, 14(4), 28-37.

Wulandari, B. (2010). Pengaruh Koefisien Hambatan Udara Pada Bentuk Lokomotif Terhadap Gaya Aerodinamis Kereta Api Argo Lawu. Skripsi Universitas Sebelas Maret. 